Philosophie in Rom - Römische Philosophie? 


\section{Beiträge zur Altertumskunde}

Herausgegeben von

Susanne Daub, Michael Erler, Dorothee Gall,

Ludwig Koenen und Clemens Zintzen

\section{Band 358}




\section{Philosophie in Rom - Römische Philosophie?}

Kultur-, literatur- und philosophiegeschichtliche Perspektiven

Herausgegeben von

Gernot Michael Müller und Fosca Mariani Zini

\section{DE GRUYTER}


ISBN 978-3-11-048872-2

e-ISBN (PDF) 978-3-11-049310-8

e-ISBN (EPUB) 978-3-11-049142-5

ISSN 1616-0452

\section{Library of Congress Cataloging-in-Publication Data}

A CIP catalog record for this book has been applied for at the Library of Congress.

\section{Bibliografische Information der Deutschen Nationalbibliothek}

Die Deutsche Nationalbibliothek verzeichnet diese Publikation in der Deutschen Nationalbibliografie; detaillierte bibliografische Daten sind im Internet über http://dnb.dnb.de abrufbar.

(C) 2018 Walter de Gruyter GmbH, Berlin/Boston

Druck und Bindung: Hubert und Co. GmbH \& Co. KG, Göttingen

@ Gedruckt auf säurefreiem Papier

Printed in Germany

www.degruyter.com 


\section{Inhaltsverzeichnis}

Gernot Michael Müller und Fosca Mariani Zini

Einleitung -1

I. Kultur- und mentalitätsgeschichtliche Grundlagen der Philosophie in Rom

Jean-Christophe Jolivet

Philosophes et philologues hellénistiques, ambassadeurs et héros culturels à

Rome: le cas de Cratès de Mallos — 43

Jochen Sauer

Römische Exempla-Ethik und Konsenskultur?

Philosophie und mos maiorum bei Cicero und Seneca - 67

II. Gesellschaftliche und literarische Rollenkonzepte für eine Selbstdefinition des Philosophen in Rom

Therese Fuhrer

Philosophische Literatur in Rom als Medium der Definition sozialer

Rollen - 99

Gernot Michael Müller

Philosophie im Plauderton.

Zum philosophischen Gehalt der Horazischen Episteln — 115

III. Griechische Philosophen und ihr römisches Umfeld im 1. Jh. v. Chr.

Georgia Tsouni

The 'Academy' in Rome: Antiochus and his vetus Academia - 139

Daniel Delattre

Philodème et le portrait moral dans le livre $X$ des Vices

([L’Arrogance], PHerc. 1008) - 151 


\section{Zum Verhältnis von Philosophie und Rhetorik in philosophischer Literatur und rhetorischer Theorie}

Michael Erler

Beweishäufung bei Lukrez. Zum Verhältnis von Philosophie und Rhetorik in philosophischer Literatur 175

Thomas Schirren

Wieviel Philosophie braucht der Redner? Zur Bedeutung der Philosophie in der Institutio oratoria des Quintilian 189

\section{Ciceros politische Philosophie und die Krise der römischen Republik}

Jonathan G. F. Powell

Philosophising about Rome. Cicero's De re publica and De legibus -249

Catherine Steel

Re publica nihil desperatius: salvaging the state in Cicero's pre-civil war philosophical works -269

\section{Skeptizismus und Erkenntnistheorie bei Cicero und Augustin}

Carlos Lévy

De la rhétorique à la philosophie:

le rôle de la temeritas dans la pensée et l'œuvre de Cicéron — 285

Tobias Reinhardt

Cicero and Augustine on Grasping the Truth -305 
VII. Argumentationstechniken für eine Philosophie als Therapie: Cicero und Seneca im Vergleich

Fosca Mariani Zini

Argumentation als Trost.

Bemerkungen über Ciceros Tusculanen, Buch I -327

Claudia Wiener

Stoa ohne stoische Terminologie? Senecas Vermittlungsstrategien - 349

VIII. Elemente einer stoischen Anthropologie für die römische Gesellschaft des 1. Jh.s n. Chr. im Guvre Senecas

Jula Wildberger

Amicitia and Eros: Seneca's Adaptation of a Stoic Concept of Friendship for Roman Men in Progress - 387

Jörn Müller

Senecas Phaedra: Stoisches Porträt einer akratischen Persönlichkeit - 427

IX. Philosophie und Naturkunde im 1. Jh. n. Chr.

Bardo Maria Gauly

Plinius' Zoologie und die römische Naturgeschichte -469

\section{Zu Rezeption und Überlieferung römischer Philosophie am Ausgang der Spätantike}

Clara Auvray-Assayas

Lectures néoplatoniciennes de Cicéron: le témoignage du manuscrit Reg. Lat. 1762 de la Bibliothèque Vaticane -491

\section{Anhang}

Index -501

Index locorum $\longrightarrow 507$ 
Bereitgestellt von | De Gruyter / TCS

Angemeldet

Heruntergeladen am | 18.12.17 11:47 


\title{
The 'Academy' in Rome: Antiochus and his vetus Academia
}

\author{
Georgia Tsouni
}

Following what David Sedley has called a period of 'decentralisation' after Sulla's siege of Athens and the subsequent closure of the Athenian philosophical schools in the First century BCE, ${ }^{1}$ Greek-speaking intellectuals who were active in the philosophical scene of Athens sought a new role. A great many emigrated to Rome and took themselves to the education of the Roman elite. ${ }^{2}$ In this essay, I would like to focus on one of them, Antiochus of Ascalon. The case of Antiochus gives as a prime example to understand the mechanisms of transmission of Greek philosophy within the context of Roman political power, and illuminates the way the new context within which Greek philosophy operated, triggered important developments both in the social role of philosophers, but also, most importantly, in the philosophical orientation of the time.

1 Sedley has identified this as "the most significant change to occur in the entire history of ancient philosophy" (David Sedley: Philodemus and the Decentralisation of Philosophy, in: Cronache Ercolanesi 33 [2003], 31-41, here 31).

2 The creation of a Greek-speaking intellectual diaspora in the Roman world was well under way in the mid of the second century BCE, when intellectuals like Polybius and Panaetius were commissioned as advisors to members of the new global political power that emerged in the Mediterranean world. Philo of Larissa, the teacher of Antiochus, had already fled from Athens to Rome in 88 BCE in an attempt to avoid Mithridates' attaque, and his lectures in Rome at this time were attended by the young Cicero exercising a decisive influence on him. Other Greekspeaking philosophers, such as Diodotus the Stoic, Phaedrus the Epicurean, Staseas of Naples and, the most known due to the survival of his works, the Epicurean Philodemus, were active in Rome in the first half of the First century BCE and probably travelled to Rome from mainland Greece in order to avoid the difficult period which followed the Roman occupation of the region. 


\section{The Defense of philosophical paideia in the First Century BCE and Antiochus}

When Antiochus made a name for himself with the movement of the 'Old Academy', activity in the physical space of the Platonic Academy at Athens had seized as a consequence of Sulla's siege. It is suggestive that at the beginning of Cicero's De finibus 5 (which takes place at the dramatic date of 79 BCE, almost seven years after Sulla's siege of Athens), Antiochus is depicted lecturing at the Ptolemaeum, a gymnasium built under the reign of Ptolemaus Philadelphos, and not in Plato's Academy. ${ }^{3}$ This is where Cicero attends the lectures of Antiochus. The different location indicates a major shift in Academic identity that took place in the first half of the First century BCE. The continuity of Plato's school is, from Antiochus onwards, not based anymore on uninterrupted institutional succession, but is constructed on the basis of a new interpretation of the Academic tradition. According to Antiochus' understanding, the 'Old Academy"s identity consists in a set of doctrines, which were endorsed by all the members of the tradition. ${ }^{4}$

The visit to the Academy that Cicero depicts at the prologue to the last book of De finibus has all the characteristics of a nostalgic tour to a place known more for its past rather than its present. In what is one of the most evocative introductions to his dialogues, Cicero describes how he and his interlocutors, his brother Quintus, Marcus Piso, T. Pomponius Atticus and Cicero's cousin Lucius visit the spot of Plato's Academy, while on a grand educational tour to the Greek world in $79 \mathrm{BC} ;{ }^{5}$ in stark contrast to the gloomy reality resulting from the Roman siege of the city some seven years before, Athens appears there as an idealised space, the birthplace of the greatest politicians, poets, rhetoricians and philosophers, whose scenes of action (although deserted) offer a reminiscence of glory and inspiration for the Roman youth: Phalerum brings to mind the great rhetorician Demosthenes, whereas the, by that time, deserted Academy, makes one re-

3 Cic. fin. 5,1: Cum audissem Antiochum, Brute, ut solebam, cum M. Pisone in eo gymnasio, quod Ptolomaeum vocatur. For the Ptolemaeum, see Paus. 1,17,2.

4 Those who did not endorse Antiochus' understanding of a unitary, 'dogmatic' Academy are considered as heterodox in Antiochean passages, see e.g. Cic. de orat. 3,67 for the Antiochean rejection of the 'sceptic' Academy after Arcesilaus and Cic. fin. 5,13-14 for the rejection of all Peripatetics after Theophrastus. The new orientation in the understanding of the Academy is signaled in Sextus Empiricus by reference to a 'fifth Academy' in relation to Antiochus' movement, after the alleged 'fourth' Academy of Philo of Larissa, see S.E.P. 1,220.

5 Fin. 5,1-5. 
member Cicero's favourite, Carneades, and the legendary debates he held on that spot many decades before. ${ }^{6}$ As Cicero puts it at De finibus 5,5:

Multa in omni parte Athenarum sunt in ipsis locis indicia summorum virorum.

In every quarter of Athens the mere sites contain many mementoes of the most illustrious men.

Athens thus appears at the beginning of the first century BCE to be on the map as an educational destination, but it is valued more as a landscape of memory, rather than of original intellectual production. In another striking passage from De oratore 3,43, the city of Athens, due to the symbolic value of education that it carries, is invested with auctoritas, a notion which unites uniquely the concepts of 'authorship' and 'authority'. This makes the city, according to Cicero, into 'a lodging for studies' from which the citizens are entirely aloof, and which are enjoyed only by foreign visitors. ${ }^{7}$ In the eyes of Cicero, Athens is the birth-place of the most important philosophers of the past, and this legitimizes its value, irrespective of its decadence in the Roman period.

The idea that Greek philosophy and its representatives carry important symbolic capital (which could have political importance as well) was shared by many in Cicero's time. A plausible explanation for Antiochus' quick adjustment to the new political reality is not only his personal charisma as a 'convincing and able speaker' ${ }^{8}$ but crucially the association of his teaching with the 'ancient tradition', which had gained value in Rome. Roman generals such as Lucius Licinius Lucullus, who became famous as the conqueror of Mithridates, were particularly keen to 'invest' on the venerable name of the Greek tradition and people like Antiochus were keenly sought to play the role of a 'friend and companion' to the political elite. ${ }^{9}$ Antiochus followed Lucullus, as a philosophical

6 Fin. 5,4.

7 Athenis iam diu doctrina ipsorum Atheniensium interiit, domicilium tantum in illa urbe remanet studiorum, quibus vacant cives, peregrini fruuntur capti quodam modo nomine urbis et auctoritate. Cf. Cic. off. 1,1: Quamquam te, Marce fili, annum iam audientem Cratippum idque Athenis abundare oportet praeceptis institutisque philosophiae propter summam et doctoris auctoritatem et urbis, quorum alter te scientia augere potest, altera exemplis, tamen, ut ipse ad meam utilitatem semper cum Graecis Latina coniunxi neque id in philosophia solum, sed etiam in dicendi exercitatione feci, idem tibi censeo faciendum, ut par sis in utriusque orationis facultate.

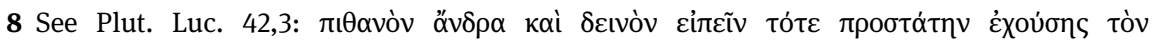

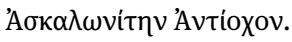

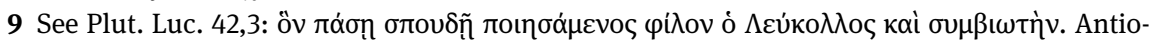
chus and Lucullus met most probably in Greece after Sulla's siege, see John Glucker: Antiochus 
advisor and perhaps also as mediator for the contacts of his Roman patron with the Greek-speaking local communities in the East, to Alexandria ${ }^{10}$ and died while at his service. ${ }^{11}$ It is from Alexandria in $87 \mathrm{BCE}$, following Lucullus, that Antiochus responds to Philo's so-called Roman books ${ }^{12}$ and, through a treatise entitled Sosus, ${ }^{13}$ for the first time openly challenges the Academic identity as represented by its institutional head. That Antiochus' teaching had an impact on other powerful Romans as well, is shown by the association of Varro and Brutus with Antiochus and his circle of students. ${ }^{14}$ Leaving aside the political role that philosophers played next to members of the Roman ruling elite, intellectual claims played a role as well: According to the testimony of Plutarch, Lucullus by associating himself with Antiochus opposed Cicero, who was Philo's student and held opposing views on key philosophical issues, such as the possibility of secure knowledge. ${ }^{15}$ The testimony of Plutarch suggests that holding pretensions to Greek wisdom by showing an interest for current philo-

and the Late Academy, Göttingen 1978 (Hypomnemata 56), 21. According to Glucker (ibid., 27) the approach of the two was based on predominantly political preoccupations: "Lucullus' choice of Antiochus [...] was made for reasons more immediately relevant to his political and military activities at the time." On the wider political benefits of acquiring a Greek speaking philosopher-advisor for Roman statesmen operating in the Hellenistic East, see ibid., 24-27. Still, Glucker seems to understate the symbolic capital associated with the pursuit of philosophical studies among the late-republican Roman elite. The latter is argued for in Michael H. Crawford: Greek intellectuals and the Roman aristocracy in the first century B.C., in: P. D. S. Garnsey; C. R. Whittaker (eds.): Imperialism in the Ancient world, Cambridge 1978, 193-207.

10 See Cic. Luc. 11.

11 According to the testimony of Cicero in Luc. 61, Antiochus died in the company of Lucullus during a campaign in Syria. The evidence from Philodemus' Index Academicorum, col. 34 also states that Antiochus spent most of his life in Rome and the eastern provinces in the service of generals and died in Mesopotamia following Lucullus. For an analysis of all the biographical evidence related to Antiochus, see Myrto Hatzimichali: Antiochus' biography, in: David Sedley (ed.): The Philosophy of Antiochus, Cambridge 2012, 9-30.

12 In Cic. ac. 11, we find the reference to two books of Philo, who reached Antiochus in Alexandria.

13 Cic. Luc. 12.

14 See Plut. Luc. 42 and Brut. 2,2 for the relationship between Brutus and Antiochus' brother Ariston. For Varro as a student of Antiochus, see Cic. ac. 1,12, as also David Blank: Varro and Antiochus, in: Sedley (ed.): Philosophy of Antiochus (as in n. 11), 250-289 and Carlos Lévy: Other followers of Antiochus, in: ibid., 9-30. Cf. also Cic. nat. deor. 1,16, where it is stated that Antiochus sent (or dedicated) a book of his to Balbus.

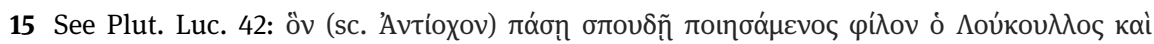

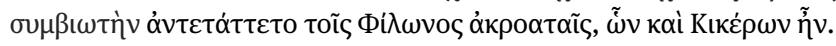


sophical debates was in the late republic a mark of distinguished rank to those who held high political offices. ${ }^{16}$

The interest in representatives of ancient wisdom, such as Antiochus, in the first half of the First century BCE is connected in Cicero with the defense of the importance of the educational role of philosophy for the young Roman elite. The didactic context of De finibus 5 (where Antiochean, i.e. 'Old Academic' ethics, is presented) is suggestive: At De finibus 5,7 Antiochus' school is advertised as the most suitable school for Lucius, the young cousin of Cicero, to follow. The relevant passage reads as follows:

Ex eorum enim scriptis et institutis cum omnis doctrina liberalis, omnis historia, omnis sermo elegans sumi potest, tum varietas est tanta artium, ut nemo sine eo instrumento ad ullam rem illustriorem satis ornatus possit accedere. Ab his oratores, ab his imperatores ac rerum publicarum principes extiterunt.

Not only may you derive from their writings and teachings (sc. of 'the Peripatetics') all liberal learning, all history, every choice form of style, but accomplishments in such variety that no one without such equipment can be properly prepared to approach any task of any distinction. From this school sprang the orators, from this school the generals and the governors of states.

Lucius, is meant to hear Antiochus' account of 'Old Academic' ethics and change his allegiance to him, since such a schooling would guarantee the greatest success in the Roman political arena. Accordingly, the importance assigned to political and rhetorical studies in the 'ancient tradition' that Antiochus represents (and more specifically, the Peripatos) is highlighted in the account of Piso, who acts as the mouthpiece of Antiochus at De finibus $5 .^{17}$

The association of the old philosophical tradition and, more specifically the Peripatos (of which Antiochus was the major representative in the first half of the First century BCE), with political theory and rhetoric testifies to the value that Roman elites placed on philosophical paideia as a supplement to rhetorical and legal forms of education during the late Republic. In Plutarch, the educational role of Greek philosophy is connected to the emerging ideal of 'liberal education', or humanitas, of which Cicero appears to be the greatest proponent. ${ }^{18}$ Cicero himself (and before him Scipio), belonged to a generation of Ro-

16 Examples for this are provided in Crawford: Greek intellectuals (as in n. 9).

17 For the same reason, the doctrines of the 'ancients' are recommended to the leading statesman Cato at fin. 4,61, as superior to those of the Stoics.

18 See e.g. fin. 5,54: Multa praeclara in illo calamitoso otio scripsit (sc. Phalereus Demetrius), non ad usum aliquem suum, quo erat orbatus, sed animi cultus ille erat ei quasi quidam humani- 
man statesmen who embraced Greek paideia and assigned to it symbolic value, contrary to the voices who were critical of the influence of Greek (philosophical) ideas on Roman society. ${ }^{19}$ Again, the important position given to the Antiochean voice in dialogues such as the De finibus forms part of the larger Ciceronian attempt to legitimise philosophical discourse for his Roman audience.

The cultivation of Greek philosophical views and its defense acquired a new meaning after the ascent of Caesar to power and Cicero's exclusion from political participation. ${ }^{20}$ During this period, exercise in philosophical thinking came to substitute the loss of the free res publica and its deliberative and judicial functions. This becomes obvious especially in the prefaces to Cicero's dialogues. There, while commenting on his own activity, Cicero goes on to compare directly the labor of the political arena with the intellectual labor, the latter being the only means of public engagement and of 'honourable leisure' (otium cum dignitate) in the hands of those who have been deprived of participation into politics. ${ }^{21}$ There is, furthermore, a sense in which the philosophical dialogue functions in Cicero's hands as a mouthpiece for the defenders of the republican order; all the speakers belong to the previous generations of optimates who held political office and who were associated with the glorious past of the res publi-

tatis cibus. Cicero is keen to present also Lucullus as a lover of Greek wisdom in the laudatory part of the homonymous dialogue, see e.g. Luc. 4. Cicero advertises in many cases in his correspondence his aspirations to Greek learning and excellent command of the Greek language and fashions himself as a lover of 'things Greek'. This becomes particularly clear in his correpondence with Atticus, see e.g. Att. 1,19,10.

19 Suggestive is Cicero's characterization as 'Greek and scholar' (ypaıкó Plut. Cic. 5,2. Cf. Att. 1,1,15. The example of Marcus Cato and Publius Africanus is invoked in Cic. Luc. 5 as precedents for the appreciation of Greek wisdom in Rome. At the same time, Cicero himself is critical of the excessive imitation of Greek manners: see e.g. fin. 1,8-9 with reference to Albucius: Res vero bonas verbis electis graviter ornateque dictas quis non legat, nisi qui se plane Graecum dici velit, ut a Scaevola est praetore salutatus Athenis Albucius? Cicero uses this as an example to rebut those who refuse the value of philosophical treatises in Latin.

20 For the political importance of the late philosophical dialogues of Cicero as a 'tool' of resistance against the authoritarian rule of Caesar, see especially Ingo Gildenhardt: Paideia Romana. Cicero's Tusculan Disputations, Cambridge 2007 (Proceedings of the Cambridge Philological Society. Supplementary Volume 30).

21 See e.g. fin. 1,10: Ego vero, cum forensibus operis, laboribus, periculis non deseruisse mihi videar praesidium in quo a populo Romano locatus sum, debeo profecto, quantumcumque possum, in eo quoque elaborare ut sint opera studio labore meo doctiores cives mei; cf. nat. deor. 1,7 and div. 2,4-5. On writing philosophy as a way to engage into 'honourable leisure', see ac. 1,11: medicinam a philosophia peto et otii oblectationem hanc honestissimam iudico. 
ca. ${ }^{22}$ Their interest in Greek philosophical ideas aims at highlighting the association of 'liberal' education of Greek provenance with the political order of the res publica and at offering a model of the ideal citizen of the republic. It is against this background, that Antiochus formulated his views of a unitary Academic tradition, the so-called 'Old Academy'. I turn now to Antiochus' teaching, and to an analysis of some of its aspects that made it such an appealing option for the Roman elite in the first half of the First century BCE.

\section{Antiochus' 'Old Academy' and the quest for philosophical origins}

Antiochus' movement explicitly appealed to the philosophical origins of the Academy, and presented its representatives as the originators of the most complete philosophical system. Thus, the success of the movement owed much, contrary to what one might expect, to its acclaimed lack of originality; it promised access to an illustrious philosophical past, while at the same time responding to the philosophical concerns that were occupying the Hellenistic schools. Suggestive for Antiochus' understanding of the Academic tradition is the following passage from Academici libri 1,17. As Varro puts it there, echoing Antiochus:

Platonis autem auctoritate, qui varius et multiplex et copiosus fuit, una et consentiens duobus vocabulis philosophiae forma instituta est Academicorum et Peripateticorum, qui rebus congruentes nominibus differebant.

Starting with Plato [Platonis autem auctoritate], a thinker of manifold variety and fertility, there was established a philosophy that, though it had two appellations, was really a single uniform system [forma], that of the Academic and the Peripatetic schools, which while agreeing in doctrine differed in name.

According to this passage, Antiochus found in Plato the origins of a complete and consistent philosophical system which was clearly articulated by Plato's successors. In line with its association with philosophical origins, Antiochus' 'Old Academy' is invested in the philosophical dialogues of Cicero with auctori-

22 For example, Q. Hortensius Hortalus, a famous orator of his time, is the main interlocutor of the homonymous dialogue which survives in a fragmentary form. Publius Cornelius Scipio Aemilianus Africanus is one of the main speakers in De re publica, together with his close associates C. Laelius, L. Furius Philus and his nephew Q. Aelius Tubero. 
tas: the word relates, on the one hand, to the originator of a branch of knowledge, as in the above mentioned passage from the Academic Books to Plato as the originator of the 'Old Academic' philosophical system, but also, on the other hand, to the power to authorize or sanction. ${ }^{23}$ In its second sense, the word carries an evaluative aspect, suggesting credibility and claims to truth. In Antiochean passages, this quality is ascribed to representatives of the 'old' philosophical wisdom, alongside legal experts and traditional members of the Roman political institutions, such as the Senate. ${ }^{24}$ This again may be adduced to explain the success of Antiochus' movement: The auctoritas of the ancients had considerable value in a society, which presented the 'customs of the forefathers' (mores maiorum) and their exempla as a constant point of validation. ${ }^{25}$

That auctoritas is used in relation to Antiochus' 'Old Academy' in Cicero and is connected with the teaching of both Plato and Aristotle constitutes a significant turning point for the orientation of Greek philosophy. Through this association Antiochus' teaching raised positive claims of reliability and enjoyed wide approval by virtue of its connection with the founding fathers of philosophy. ${ }^{26}$ Similarly, gravitas, alongside auctoritas a marker of social recognition and influence, is invoked in Antiochean passages to characterise the teaching of the 'Old Academy'. ${ }^{27}$

The quest of origins in all branches of knowledge was accompanied in the first century BCE by the desire to create repositories of wisdom in the new centres of power. Antiochus wrote in a period when the so-called 'esoteric works' of Aristotle were being rediscovered. The official story, based on the evidence of

23 For an overview of the different meanings of the word, see Richard Heinze: Auctoritas, in: Hermes 60 (1925), 348-366.

24 For preoccupation with the auctores or 'originators' of a field of study who may serve as models, cf. also Cic. de orat. 3,148 and with regard to the field of rhetoric, see veteres doctores auctoresque dicendi in ibid. 3,126.

25 For a direct comparison between the ancient philosophers and the Roman forefathers, see Cic. fin. 4,62.

26 Cf. David Sedley: Plato's auctoritas and the Rebirth of the Commentary Tradition, in: Jonathan Barnes; Miriam Griffin (eds.): Philosophia Togata II. Plato and Aristotle at Rome, Oxford 1997, 110-129, here 111: "Yet it is this Latin word which, by combining the notions of leadership, ownership, prestige, and validation, most informatively conveys the commanding status that the founder (the auctor) of a Greek philosophical system held in the eyes of its subsequent adherents."

27 It is suggestive that the Peripatos after Theophrastus is in Piso's account at fin. 5,13 condemned by virtue of lacking gravitas: concinnus deinde et elegans huius, Aristo, sed ea, quae desideratur a magno philosopho, gravitas, in eo non fuit; scripta sane et multa et polita, sed nescio quo pacto auctoritatem oratio non habet. 
both Strabo and Plutarch, suggests that after the conquest of Athens, Sulla took possession of Appellicon's library, which contained the school treatises of both Aristotle and Theophrastus, and brought it as booty to Rome. ${ }^{28}$ Due to their pedigree and antiquity, the treatises were met with interest and following this, the first attempts at their meticulous study were made by a circle of grammarians, of whom Tyrannion is best known.

Beyond being an admirer of Greek learning, Lucullus, the patron of Antiochus, was in the possession of a library, which was housed in his hereditary estate in Tusculum. Suggestive of the new importance assigned to collections of manuscripts in this period is that such a library complex becomes the background of Cicero's De finibus 3; the book features Cicero going to the mansion of the young Lucullus in his search for some Aristotelian treatises (commentarii) and finding there Cato the Younger studying the Stoics. ${ }^{29}$ The availability of Aristotelian treatises in Lucullus' estate suggests that it was a repository of Greek wisdom, most probably for material coming from Greece. This is confirmed by evidence in Plutarch, who refers to Lucullus' mansion as 'a home and

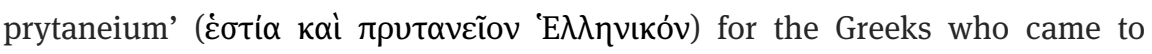
Rome. ${ }^{30}$

One may assume that through his association with Lucullus, Antiochus also gained access to his library, and was engaged into the interpretation of the texts that were available there. A plausible hypothesis is that Antiochus was among

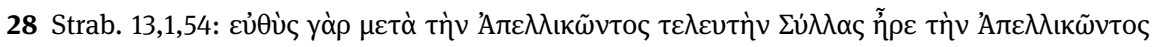

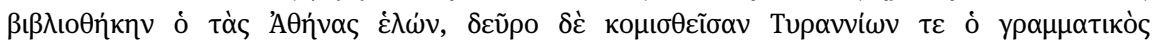

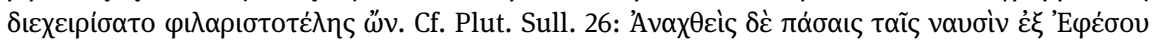

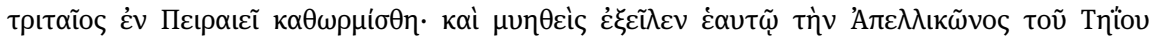

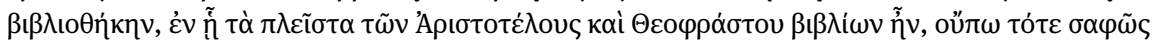

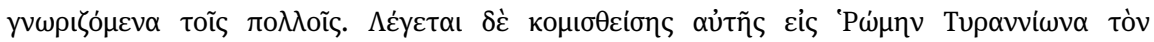

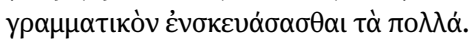

29 See fin. 3,7: Nam in Tusculano cum essem vellemque e bibliotheca pueri Luculli quibusdam libris uti, veni in eius villam ut eos ipse, ut solebam, depromerem. Quo cum venissem, $M$. Catonem, quem ibi esse nescieram, vidi in bibliotheca sedentem, multis circumfusum Stoico-rum libris and ibid. 3,10 (Cicero speaking): 'Commentarios quosdam' inquam 'Aristotelios, quos hic sciebam esse, veni ut auferrem, quos legerem dum essem otiosus.'

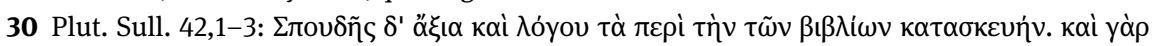

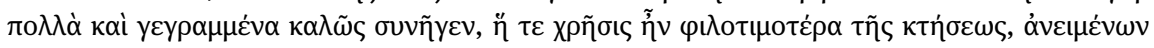

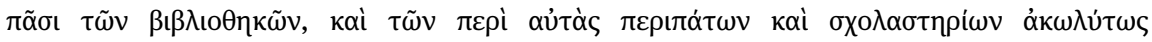
ن்

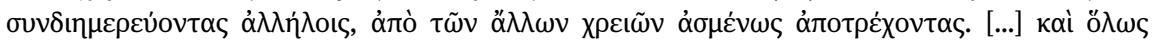

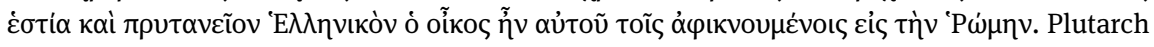
refers also to Lucullus' admiration for the grammarian Tyrannion at Luc. 19,7. There is no evidence, though, for an association of Tyrannion with Antiochus. 
the first to read again the school treatises of the Academy and the Peripatos with a view to reconstructing their meaning and for the purpose of transmitting their teaching to, a primarily, Roman audience. This is confirmed by evidence from Piso's speech at De finibus 5,9-11; The Antiochean account of ethics begins there with a reference to the school treatises of the Peripatos on all three major (Hellenistic) areas of philosophical research, namely physics, ethics and dialectic. ${ }^{31}$ The reference serves to show the sources from which Antiochus drew for his teaching. By drawing on the Peripatetic school treatises for his reconstruction of the 'Old Academic' philosophical system, Antiochus could invest his teaching with 'authoritative' sources. This gradually heralded a new period in the history of philosophy, characterized by the return to the very lexis of philosophical authorities. ${ }^{32}$

\section{Conclusion}

Antiochus was the first philosopher to offer a dogmatic reconstruction of Platonic and Peripatetic thought to a large Roman audience after the Academy's abrupt interruption as a living institution. His dogmatic interpretation of the Academic tradition and his attempt to involve Aristotle in the understanding of this tradition, although not long-lasting as an official school, ${ }^{33}$ remained extremely influential in the subsequent centuries and, indirectly, still shape our understanding of both Plato and Aristotle as the principes of the philosophical discipline. I have argued that Antiochus' movement was both supported by the changing role of the educational value of Greek philosophy among the Roman elite during the first half of the First century BCE, as also by the authority assigned to philosophical origins during this era. These two factors contributed significantly to the popularity of the 'Old Academic' movement in the late Ro-

31 See for example the reference to the zoological and botanical treatises of Aristotle and Theophrastus respectively, at fin. 5,10: Aristoteles animantium omnium ortus, victus, figuras, Theophrastus autem stirpium naturas omniumque fere rerum, quae e terra gignerentur, causas atque rationes.

32 It is suggestive that Antiochus is not regarded as an 'exegete' in the Aristotelian tradition, contrary to Peripatetics of the second half of the First century BCE like Xenarchus. On the latter, see Andrea Falcon: Aristotelianism in the First century BCE, Cambridge 2012, esp. 21-25. 33 Antiochus' school was continued after his death in 69 BCE by his brother Aristus and Aristus' own successor Theomnestus. But there is no recorded trace of it after the 40s BCE. 
man republic, alongside of course the influence exercised by the content of the philosophical doctrines, that Antiochus attributed to the 'ancients', themselves. 
Bereitgestellt von | De Gruyter / TCS

Angemeldet

Heruntergeladen am | 18.12.17 11:57 